\title{
THE RESTRICTIONS OF RETROACTIVE LEGISLATION: CONCEPTION AND LEGAL CHALLENGES
}

\author{
Māris Onževs \\ University of Latvia \\ Raina 19, LV-1586, Riga \\ Telephone: +37126702420 \\ E-mail: maris_onzevs@yahoo.com
}

Submitted on 5 May 2013, accepted on 20 September 2013

doi:10.13165/JUR-13-20-4-04

\section{Introduction}

More and more often there are appearing cases, when a legislator implements amendments to legislation related to changes in events ${ }^{1}$ fully completed or completion of which has been commenced in the past. Also, this is clearly represented in the law of Germany, European Union (hereinafter - EU) and Latvia. For example, legislator may impact the events related to past dimension changing previously prescribed support payments to subjects of legal norms ${ }^{2}$, similarly, legislator may reduce the awarded benefits and pensions $s^{3}$ and stipulate that, after promulgation of the amendments,

1 The term "event" is used in the article to describe application of amendments of legal norms to real-life situations that have already happened or are continuing prior to enactment of amendments. For example, it might come into effect if amendments of legislation prescribing other consequences to already concluded rent or loan agreements, taxable actions already occurred, compensations awarded, existing entitlement to a certain number of vacation days etc., are passed.

2 Case C-113/10, Zuckerfabrik Jülich and Others [2012]. ECR I-0000.

3 Ruling No. 2009-43-01 of 21 December 2009 by the Constitutional Court of the Republic of Latvia. 
insurance agreements concluded shall be fulfilled according to other regulations and not to those effective at the date of concluding agreements ${ }^{4}$.

On the one hand, in a state of law, it is acknowledged that legislator has comparatively vast discretion and authority to determine the binding nature of legal norms in time related to past dimension in the process of legislation ${ }^{5}$. However, on the other hand, discretion of legislator, when determining time dimension of applicability of a legal norm, has been restricted by the duty to consider fundamental rights and general principles of law ${ }^{6}$. Thus, considering the extent of impact and deterioration established by the scope of amendments ${ }^{7}$, at first, legislator shall assess whether the amendments infringe the existing rights of the subjects of legal norms, including rights of legal security, legal certainty and legitimate expectations.

In light of the legal practice to evaluate the compliance of amendments with legal security and certainty principles ${ }^{8}$, further on in the article, the comprehension existing in the European law of restrictions established on discretion of legislator on the basis of retroactivity is revealed, in other words, doctrine of retroactivity is viewed as a method implemented in the constitutional law during the last 50 years, which protects against changes in the existing legal regulation and prevents from disproportionate interference with the past dimension.

However, until nowadays, in the legal system of Latvia, problems regarding retroactivity have not been widely researched - the aforementioned issue has been viewed only in a couple of court rulings. The main doctrinal aspects, i.e. the understanding of legal norms with a retroactive and an immediate temporal effect, identification methods of retroactive legal norms and admissibility of retroactivity originated from the legal doctrine and court rulings of the Western Europe, starting from the second half of the 20th century. The most authoritative sources are rulings of the Federal Constitutional Court of Germany (hereinafter - the Constitutional Court of Germany), which are not only used as a ground for several researches, doctoral thesis and monographs, but are quoted as an important argument in the rulings of the Constitutional Court of Latvia.

Latvijas Véstnesis. No. 201(4187), 22.12.2009. Ruling No. 2009-86-01 of 21 April 2010 by the Constitutional Court of the Republic of Latvia. Latvijas Véstnesis. No. 65(4257), 23.04.2010.

4 Neuhaus, K.J.; Kloth, A.; Köther, L. Neue Frist, alte Verträge - Wann ist ein Altvertrag mit mehrjähriger Laufzeit kündbar. Zeitschrift für Versicherungswesen. March 2009: 180-183. Funck, J.; Pletsch, H.J. Wann ist ein Fünfjahres(alt)vertrag kündbar? Versicherungsrecht. 2009, 13: 615.

5 Ruling No. 2 BvL 18/83 of 10 December 1985 by the Second Senate of the Constitutional Court of Germany. Published: Entscheidungen des Bundesverfassungsgerichts, Vol. 71. Tübingen: J.C.B. Mohr (Paul Siebeck), 1986, p. 255-275 (p. 272-273). Ruling No. 1 BvR 820, 1033/76 of 21 December 1977 by the Second Senate of the Constitutional Court of Germany. Published: Entscheidungen des Bundesverfassungsgerichts, Vol. 47. Tübingen: J.C.B. Mohr (Paul Siebeck), 1978, p. 86-102 (p. 93).

6 Maurer, H. Kontinuitätsgewähr und Vertrauensschutz. In: Isensee, J.; Kirchhof, P. Handbuch des Staatsrechts. Vol. IV. Heidelberg: C.F.Müller Verlag, 2006, p. 396. See also $§ 13.2$ of the Ruling No. 2010-21-01 of 1 December 2010 by the Constitutional Court of the Republic of Latvia. Latvijas Véstnesis. No. 192(4384), 03.12.2010.

7 See, for example, $\S 21$ of the Ruling No. 2006-04-01 of 8 November 2006 by the Constitutional Court of the Republic of Latvia. Latvijas Vèstnesis. No. 183(3551), 15.11.2006.

8 Maurer, H. Staatsrecht. München: C.H. Beck'sche Verlagsbuchhandlung, 1999, p. 589. 
Considering comparatively specific development of the doctrine of retroactivity and its application in different legal systems, it is not possible to analyse all the differences in retroactivity comprehension, existing in various legal systems. Therefore, the article focuses on comprehension of retroactivity existent in the German law as the basis of establishment and development of the modern doctrine and further application in the European law $^{9}$. Along with analysis of the German case-law and doctrine, restrictions established on passing retroactive legal norms in the EU law also have been viewed as a representation of the understanding of solving doctrinal rights issues existent in laws of its Member States.

\section{General understanding of restricting legislator to pass legal norms with a retroactive effect}

\subsection{Historical development of understanding of retroactive legal norms}

In a state of law, interference with the past dimension and infringement of the existing legal interests most explicitly is related to duty of a legislator to refrain from passing retroactive legal norms. Hence, it is important to emphasize that systematic and comprehensive restricting of legislator from passing retroactive legal norms has existed in the continental Europe only since the second half of the 20th century, when effective monitoring of legislators' discretion was established through the constitutional courts.

Although since the Ancient Rome separation of legal norms related to past dimension by intensity of their effect and negative attitude towards retroactivity has existed $^{10}$, until the 50 s and 60 s of the 20 th century theses on temporal effect of the legal norms have been mainly focused on identifying temporal dimension of applicability of legal norms, i.e., interpretation of legal norms in case of unclear regulation rather than assessment of rule of law. Therefore, although prima facie it might appear that regulation included in codifications of private law carried out in the 18th and 19th centuries and expressis verbis indicating the inadmissibility of retroactivity should be applied also to restrictions established on legislator to refrain from impacting performed events in the past, legal doctrine clearly states that the respective legal norms cannot be considered as binding legal basis to refrain legislator to pass retroactive legal norms ${ }^{11}$. Hence, statement of Article 14 of the General Law Code for the Prussian States of 1794 (Allgemeine Landrecht für die Preußischen Staaten) saying that "new laws cannot be

9 Steiner, J.; Woods, L. Textbook on EC Law. 8th edition. New York: Oxford University Press, 2003, p. 168.

10 Vonkilch, A. Das Intertemporale Privatrecht. Übergangsfragen bei Gesetzes- und Rechtsprechungsänderungen im Privatrecht. Wien: Springer Verlag, 1999, p. 15-17.

11 Lamoureux, F. The Retroactivity of Community Acts in the Case Law of the Court of Justice. Common Market Law Review. 1983, 20(2): 269-297. Maurer, H. Kontinuitätsgewähr und Vertrauensschutz. In: Isensee, J.; Kirchhof, P. Handbuch des Staatsrechts. Vol. IV. Heidelberg: C.F.Müller Verlag, 2006, p. $410-411$. 
applied to actions and events that occurred in the past"12, principle implied in Article 2 of Civil Code of France of 1804 stating that "legislation provides only for the future; it has no retrospective operation"13 and Article 5 of the Austrian Civil Code adopted in 1811 stating that "laws do not have retroactive effect, they have no impact on previous actions and rights obtained previously" 14 are regarded as intertemporal law principles, i.e., legal norms provided to interpret the will of legislator rather than refraining legislator to pass retroactive legal norms.

\subsection{Restrictions to pass retroactive legal norms after World War II}

It is important to understand that in contrast to the existing division of legal norms by their temporal effect - retroactive, immediate and in the future binding effect - within the framework of contemporary theory of law, until the second half of the 20th century, all legal norms were doctrinally divided only in two parts by the temporal dimension of applicability. On the basis of the principle on "non-retroactivity" of legal norms (German -Nicht-Rückwirkung ${ }^{15}$ ), the following separation of legal norms was made: on the one hand, those were legal norms, the binding nature of which impacts the performed events in the past, and on the other hand, those were legal norms, which influenced the events occurred after passing the legal rights ${ }^{16}$. Moreover, as it is clearly verified by codifications of law carried out during the 18th and 19th centuries, all legal norms with any relation to regulating events in the past - both as regards already performed events and events related only to the past - were jointly called using a general term "retroactive effect in time" 17 .

In light of the abovementioned - with neither clear understanding of the extent to which legislator has been restricted to interfere with the past dimension, nor precise correlation between retroactivity and duty of legislator to refrain from interfering with the past dimension - after World War II, when a comprehensive monitoring of legislator's discretion was commenced, at first, legal norms that due to interfering with the past dimension are considered illegitimate had to be identified. Consequently, changes in the understanding of retroactivity were not rapid but lasted several years defining retroactivity anew and type of relation between retroactivity and inadmissibility to

12 Article 14 of the General Law Code for the Prussian States. Cited by: Hess, B. Intertemporales Privatrecht. Tübingen: Mohr Siebeck, 1998, p. 61.

13 Article 2 of the Civil Code of France. Civil Code of France [interactive]. [accessed on 08-07-2013]. $<$ http://lexinter.net/ENGLISH/civil_code.htm $>$.

14 Article 5 of the Austrian Civil Code. Austrian Civil Code [interactive]. [accessed on 08-07-2013]. <http:// www.ibiblio.org/ais/abgb1.htm>.

15 Heukels, T. Intertemporales Gemeinschaftsrecht. Rückwirkung, Sofortwirkung und Rechtsschutz in der Rechtsprechung des Gerichtshofes der Europäischen Gemeinschaften. Baden-Baden: Nomos Verlagsgesellschaft, 1990, p. 50.

16 Ibid.

17 Maurer, H. Kontinuitätsgewähr und Vertrauensschutz. In: Isensee, J.; Kirchhof, P. Handbuch des Staatsrechts. Vol. IV. Heidelberg: C.F.Müller Verlag, 2006, p. 404; Krons, M. Intertemporālo tiesību mācība un Civillikuma trešais pants. Tieslietu Ministrijas Vēstnesis. 1938, 1: 83-115. 
interfere with the past dimension ${ }^{18}$. Facing the necessity to define a completely different retroactivity - that would ensure cancelling eventually illegitimate legal norms - there were clear deficiencies in division of temporal dimensions of applicability of the existing legal norms. For example, more than ten years after its establishment, the Constitutional Court of Germany was not able to define neither the scope of retroactivity, nor the state whether such effect of legal norms was generally acceptable ${ }^{19}$.

Analysing admissibility of legal norms regulating events related to the past, the Constitutional Court of Germany was initially indicating generally that retroactive effect is related to retroactive interference in all situations regulated by the law ${ }^{20}$. At the same time, the Court justified that although retroactivity is substantially permissible, it shall be prohibited in cases, when persons were not able to estimate and take into account potential changes with retroactive effect objectively ${ }^{21}$. In light of the above stated, a conclusion could be drawn that the only linking feature of identifying retroactive nature of law, similarly as in the Ancient Rome, is any obvious relation with the past dimension. Therefore, with no objectively definable content criteria and methodology for recognition of retroactivity, assessment of admissibility could be performed on the basis of an individual analysis of existence of retroactivity in its widest sense and afterwards admissibility of each legal norm under analysis.

Although understanding of the concept of retroactivity developed along with almost every ruling by the Constitutional Court of Germany, in which the aspects under review were related to evaluation of temporal scope of the legal norms, the above understanding of retroactivity as a wide concept existed until ruling in the case No. Nr.2 BvL 4/59 of 31 May 1960 by the Constitutional Court of Germany ${ }^{22}$. The ruling referred to above, in the legal doctrine considered the basis and turning point of the present understanding of a precise and systematic separation of events related to the past $\mathrm{t}^{23}$, is the commencement

18 Stern, K. Zur Problematik rückwirkender Gesetze. Festschrift für Theodor Maunz. Zum 80. Geburtstag. München: C.H. Beck'sche Verlagsbuchhandlung, 1981, p. 381-395.

19 Stötzel, M. Vertrauensschutz und Gesetzesrückwirkung. Grundtypen abgeleitet aus der Rückwirkungsrechtsprechung des Bundesverfassungsgerichts. Frankfurt am Main: Peter Lang Europäischer Verlag der Wissenschaften, 2002, p. 81-82.

20 Ruling No. 1 BvR 14, 25, 167/52 of 30 April 1952 by the First Senate of the Constitutional Court of Germany. Published: Entscheidungen des Bundesverfassungsgerichts, Vol. 1. Tübingen: J.C.B. Mohr (Paul Siebeck), 1952, p. 264-281 (p. 279-280).

21 Ibid.; Ruling No. 1 BvR 102/51 of 24 April 1953 by the First Senate of the Constitutional Court of Germany. Published: Entscheidungen des Bundesverfassungsgerichts, Vol. 2. Tübingen: J.C.B. Mohr (Paul Siebeck), 1953, p. 237-266 (p. 264-265).

22 Ruling No. 2 BvR 4/59 of 31 May 1960 by the Second Senate of the Constitutional Court of Germany. Published: Entscheidungen des Bundesverfassungsgerichts, Vol. 11. Tübingen: J.C.B. Mohr (Paul Siebeck), 1961, p. 139-149.

23 Berger, T. Zulässigkeitsgrenzen der Rückwirkung von Gesetzen. Eine kritische Analyse der Rechtsprechung des Bundesverfassungsgerichts und des Gerichtshofs der Europäischen Gemeinschaften. Frankfurt am Main: Europaeischer Verlag der Wissenschaften, 2002, p. 48. Maurer, H. Kontinuitätsgewähr und Vertrauensschutz. In: Isensee, J.; Kirchhof, P. Handbuch des Staatsrechts. Vol. IV. Heidelberg: C.F.Müller Verlag, 2006, p. 405. 
of the modern understanding of separation of retroactivity as an unacceptable impact on the performed events in the past.

Namely, reviewing the case No. 2 BvL 4/59, the Constitutional Court of Germany had to establish whether amendments to the Court Costs Law (Gerichtskostengesetz), according to which state duty was increased also to disputes on setting rent payments under review of the court, which, until the amendments becoming effective, were not completed in the respective court instance, are legitimate from the point of view of time ${ }^{24}$. According to the abovementioned, the Constitutional Court of Germany concluded that increasing of state duties in respect to disputes in progress, commenced prior to adoption of regulation, is legitimate.

At the same time, to solve the abovementioned dispute and justify methodologically the cases when performed events of the past are unacceptable, the Constitutional Court of Germany established the first doctrinal concept of retroactivity. Within the framework of identifying the retroactivity, it was considered that if legislator, amending legal regulation has impacted performed events (completed legal elements) prior to the amended legal norms become effective, it is believed that legal norm has a genuine retroactive effect in time (German - echte Rückwirkung) and such norms shall be prima facie illegitimate ${ }^{25}$. However, if the binding nature of a legal norm can be applied to legal relations or events commenced previously and continuing as at the date of the norm becoming effective, "quasi retroactive effect" (German - unechte Rückwirkung) ${ }^{26}$ shall be established, which in other legal systems is denoted by term "immediate temporal effect" and prima facie is considered legitimate.

\section{Relative nature of prohibition to pass retroactive legal norms: separation from the initial criminal law principle "nulla poena sine lege"}

Therefore, although since the ruling of the Constitutional Court of Germany, caselaw and doctrine include a concept that, when establishing a retroactive legal norm, legislator's interference with the past dimension is considered illegitimate, it has to be noted that prohibition to pass retroactive legal norms has a relative nature. In other words, although retroactive legal norms passed might significantly impact the legitimate expectations of subjects of legal norms, those as not per se considered illegitimate, but are subjected to an extended assessment of legitimate expectations. Consequently, the conclusion implying that legislator is entirely precluded from passing retroactive legal norms is not grounded.

24 Ruling No. 2 BvR 4/59 of 31 May 1960 by the Second Senate of the Constitutional Court of Germany. Published: Entscheidungen des Bundesverfassungsgerichts, Vol. 11. Tübingen: J.C.B. Mohr (Paul Siebeck), 1961, p. 139-149.

25 Ibid.

26 Ibid. 
The incorrect comprehension of absolute illegitimacy of retroactivity might be related to the fact that legislator's interference with the past dimension is related mainly to the prohibition existing mostly in the criminal law to impose punishment with a retroactive effect in time. However, the principle "nulla poena sine lege" or "no penalty without a law"27 restricting existence of retroactivity is completely different and not related to prohibition of retroactivity in other law fields that prescribes both historically and substantially other guarantees to subjects of legal norms.

The main difference between the disclosing method applied to retroactive effect as a principle of legitimate expectation and the principle "nulla poena sine lege" is related to consideration that by stating penalty it is absolutely prohibited to pass retroactive legal norms ${ }^{28}$ that deteriorate the legal standing of persons. Outside the penal law, retroactive effect in time is not prohibited absolutely and provided that there are conditions justifying public interest, in certain cases legislator is entitled to impact subjects of legal norms also with such a level of intensity. Moreover, prohibition to impose punishment with a retroactive effect or extend it for previous actions in the criminal law has all the preconditions of general principles of law and it shall be per se considered an independent principle of general law ${ }^{29}$. Namely, although the respective principle has been included in Article 7 of the European Convention on Human Rights and Fundamental Freedoms ${ }^{30}$ and in legal regulation of various states on the constitutional level ${ }^{31}$, as well as in the normative acts regulating punishment ${ }^{32}$, the principle "nulla poena sine lege" shall be complied without being included in the normative acts.

27 Scheb, M.J. Criminal Law. 5th edition. Belmont: Wadsworth, 2009.

28 Fiedler, J. Neuorientierung der Verfassungsrechtsprechung zum Rückwirkungsverbot und zum Vertrauensschutz. Neue Juristische Wochenschrift. 1988: 1624-1631. Ruling No. 2 BvR 2029/01 of 5 February 2004 by the Second Senate of the Constitutional Court of Germany. Published: Entscheidungen des Bundesverfassungsgerichts, Vol. 109. Tübingen: Mohr Siebeck, 2004, p. 133-190 (p. 167-168).

29 “(...) the principle that penal provisions may not have retroactive effect is one which is common to all the legal orders of the Member States and is enshrined in Article 7 of the European Convention for the Protection of Human Rights and Fundamental Freedoms as a fundamental right which takes its place among the general principles of law whose observance is ensured by the Court of Justice". $\S 42$ of Case C-331/88, The Queen v Ministry of Agriculture, Fisheries and Food, ex parte FEDESA and Others [1990]. ECR I-04023.

30 "No one shall be held guilty of any criminal offence on account of any act or omission which did not constitute a criminal offence under national or international law at the time when it was committed. Nor shall a heavier penalty be imposed than the one that was applicable at the time the criminal offence was committed'. Convention for the Protection of Human Rights and Fundamental Freedoms (adopted 4 November 1950, entered into force 3 September 1953). ETS 5; 213 UNTS 221 (ECHR).

31 Article 103(2) of the Constitution of the Federal Republic of Germany: "An act may be punished only if it was defined by a law as a criminal offence before the act was committed" (Eine Tat kann nur bestraft werden, wenn die Strafbarkeit gesetzlich bestimmt war, bevor die Tat begangen wurde). Constitution of the Federal Republic of Germany. Bundesgesetzblatt. 1949, p. 1.

32 See, for example, Article 5(1) of the Criminal Law of Latvia: "The criminality and punishability of an offence (act or failure to act) are determined by the law, which was in force at the time the offence was committed", (3): "A law, which recognises an offence as punishable, increases the punishment, or is otherwise not beneficial to a person, does not have retrospective effect"'. Criminal Law. Latvijas Vèstnesis. 1998, No. 199/200 (1260/1261).

Article 8(1) of the Latvian Code of Administrative Violations: "A person who has committed an administrative violation shall be liable in accordance with the law, which was in force at the time and place of the 
Understanding of prohibition of retroactivity in criminal and punishment field in general is explicitly separated not only in the legal doctrine ${ }^{33}$, but also in the case-law. For example, the Constitutional Court of Germany has stated that prohibition included in Article 103(2) of the Constitution of the Federal Republic of Germany, the same as the abovementioned one to impose punishment for actions performed in the past, cannot be considered an absolute principle in respect to other situations, when legislator would apply retroactive effect on the legal norms ${ }^{34}$. In addition to the above stated, legal doctrine indicates that in legitimate expectations of subjects of legal norms in the criminal law cannot be correlated with the public interes ${ }^{35}$ and, therefore, even in exceptional cases, society cannot have higher interests than expectations of subjects of legal norms on knowledge of legitimate and illegitimate actions ${ }^{36}$. At the same time, it has to be emphasized that prohibition prescribed by the criminal law has to be understood narrowly and it shall not be applied to the additional punishment ${ }^{37}$. Moreover, both the Court of Justice of the European Union (hereinafter - ECJ) and the European Court of Human Rights (hereinafter - ECHR) in their case-laws have stated that retroactive punishing is a fundamental invasion of human rights ${ }^{38}$.

\section{Legal challenges of restricting legislator to pass legal norms with a retroactive effect}

\subsection{Problem of identifying retroactive legal norms}

It has to be noted that in some cases retroactivity can be detected comparatively simply. For example, if the legal norm under assessment expresis verbis specifies that impact of legal regulation shall be commenced in the period of time prior to the date, the legal regulation becomes effective ${ }^{39}$. Similarly, it is simpler to recognise retroactivity

committing of the violation”, (2): “(..) Acts, which determine or aggravate liability regarding administrative violations, shall not have a retrospective effect". Zinotājs. 1984, No. 51.

33 Maurer, H. Staatsrecht. München: C.H. Beck'sche Verlagsbuchhandlung, 1999, p. 588.

34 Ruling No. 2 BvL 2/83 of 14 May 1986 by the Second Senate of the Constitutional Court of Germany. Published: Entscheidungen des Bundesverfassungsgerichts, Vol. 72. Tübingen: J.C.B. Mohr (Paul Siebeck), 1987, p. 200-276 (p. 257-258).

35 Brüning, C. Die Rückwirkung von Legislativakten. Neue Juristische Wochenschrift. 1998: 1525-1528.

36 For prohibition of retroactivity in the criminal law, see Wernsmann, R. Grundfälle zur verfassungsrechtlichen Zulässigkeit rückwirkender Gesetze. Juristische Schulung. 1999, 12: 1177-1780.

37 Ruling No. 2 BvR 2029/01 of 5 February 2004 by the Second Senate of the Constitutional Court of Germany. Published: Entscheidungen des Bundesverfassungsgerichts, Vol. 109. Tübingen: Mohr Siebeck, 2004, p. 133-190 (p. 167-168).

$38 \S 22$ of Case C-63/83, Regina v Kent Kirk [1984]. ECR 02689. G v. Germany, No. 65210/09, ECHR.

39 The respective construction shall be detected most often, when the legal regulation includes a precise date, as of which the legal regulation becomes applicable, for example, 02.06.2009. Regulation of Cabinet of Ministers No. 511 "Amendments to Regulation of Cabinet of Ministers No. 740 "Regulations regarding Stipends"'. Latvijas Véstnesis. 2009, No.107(4093) (effective as of 10 July 2009, applicable as of 1 July 2009). 
in cases, when legal norm expresis verbis does not imply that it shall be applied as of the date of its promulgation, but legal norms or legislation materials include indirect indications on legislator's intention to impact the existence of retroactivity. These indications might provide additional arguments to identify retroactivity; however, it cannot establish legal grounds for the final conclusions on existence of retroactivity.

However, disputes on existence of retroactivity most often are related to situations when the only "source data" for subjects of legal norms and persons, who apply legal norms, is a pure legal norm expressing a wish of legislator to regulate legal issue impacting events of the past at the same time. For example, without specifying expresis verbis, whether legal norm is retroactive, legislator may pass amendments to legal regulation prescribing that trading permits shall be terminated ${ }^{40}$. Moreover, legislator may implement further changes in state policy limiting support for energy production projects $^{41}$, as well as changing pre-conditions, which are compulsory to continue fulfilling their duties ${ }^{42}$. Therefore, in these situations, it has to be mainly identified whether legislator has interfered with the past dimension with a retroactive effect in time and thereby conclude whether amendments are unlawful.

In relation to identification of retroactivity, it should be noted that both as a result of development of case-law and on basis of conclusions of legal doctrine, nowadays it is possible to identify retroactivity applying three different methods:

1) method, identifying retroactivity on basis of doctrine of completeness of legal elements (performed events) ${ }^{43}$

2) method, identifying retroactivity through recognition of impact of legal consequences prior to promulgation of the legal regulation ${ }^{44}$;

3) identification of retroactivity through recognition of violation of vested rights prior to promulgation of regulation ${ }^{45}$.

40 For example, European Court of Human Rights has specified that when Moldova has restricted further operations of "duty free" stores, it has violated rights of owners of stores with a retroactive effect in time. BIMER S.A. v. Moldova, No. 15084/03, ECHR.

41 Board Member of the Latvian Biomass Association "LATbio" and European Biomass Association Didzis Palejs stated that "Latvian government is at present deteriorate the operating environment of producers of renewable energy prescribing new restrictions with a retroactive effect and changing legal regulation of energy sphere radically." 'Zaḷās energijas' biedrības sūdzas EK par nozares atstāšanu novārtā [interactive]. [accessed on 08-07-2013]. <http://www.delfi.lv/bizness/biznesa_vide/zalas-energijas-biedribas-sudzas-ek-par-nozares-atstasanu-novarta.d?id=42844298>.

42 See more in: Onževs, M. Par neīsta atpakaḷejoša spēka izpratni Latvijas tiesu nolēmumos. Jurista Vārds. 2013, 12(763).

43 Ibid.

44 Heukels, T. Intertemporales Gemeinschaftsrecht. Rückwirkung, Sofortwirkung und Rechtsschutz in der Rechtsprechung des Gerichtshofes der Europäischen Gemeinschaften. Baden-Baden: Nomos Verlagsgesellschaft, 1990, p. 68.

45 Lindemann, H.H. Allgemeine Rechtsgrundsätze und europäischer öffentlicher Dienst. Berlin: Duncker \& Humblot, 1986, p. 136. Raitio, J. The Principle of Legal Certainty as a General Principle of EU Law. General Principles of EC Law in a Process of Development. Kluwer Law, 2008, p. 54; Heukels, T. Intertemporales Gemeinschaftsrecht. Rückwirkung, Sofortwirkung und Rechtsschutz in der Rechtsprechung des Gerichtshofes der Europäischen Gemeinschaften. Baden-Baden: Nomos Verlagsgesellschaft, 1990, p. 56. 
Although each method identifying retroactivity is based on different objects, on basis of which intensity of legal norm can be assessed, as a result of applying all the methods, an identical conclusion shall be reached on existence of retroactivity ${ }^{46}$. Irrespective of the above stated, it is acknowledged that there is not only lack of knowledge on application of methods to identify retroactivity in practice ${ }^{47}$, but also, due to objective reasons, there might be issues of adequate application of the respective doctrines.

For example, legal doctrine specifies that there is still no solution on how subjective detection of performed events may be prevented ${ }^{48}$ that does not allow to conclude when the completeness of legal elements can be detected. Comparatively high non-flexibility of the above doctrines is an issue, e.g., methodology of setting legal consequences lacks clear and joint criteria to review all disputes that consequently tolerate manipulating of the doctrine by legislator ${ }^{49}$. Similar arguments have been also given, as regards the doctrine on completeness of legal elements ${ }^{50}$. Doctrine of vested rights, however, is indicated as applicable in identifying retroactivity of such amendments to legal norms that have been passed in rights of civil servants and social rights ${ }^{51}$.

Problems of identifying retroactivity have been revealed not only by legal scholars, but also by the Constitutional Court of Germany itself. For example, in the end of the 60 s of the 20th century, the court acknowledged that arguments and methods used to detect "completeness" in legal disputes analysing existence of "genuine retroactive effect" are so unclear that it is possible to precisely detect retroactivity of simple situations only ${ }^{52}$. However, the efforts to eliminate problems of the doctrine of the court have not been completely successful. Namely, in the beginning of the 80s of the 20th century, the doctrine implemented by the Constitutional Court of Germany prescribing

46 For example, in cases, when possible violation of legitimate expectations of subjects of legal norms is assessed on the basis of doctrine on retroactive effect of legal consequences, the Constitutional Court of Germany along with the respective doctrine has added also the doctrine of completeness of legal elements. Ruling No. 2 BvR 748, 753, 1738/05 of 7 July 2010 by the Second Senate of the Constitutional Court of Germany. Published: Entscheidungen des Bundesverfassungsgerichts, Vol. 127. Tübingen: J.C.B. Mohr (Paul Siebeck), 2011, p. 61-87 (p. 75).

47 Onževs, M. Par nē̄sta atpakal̦ejoša spēka izpratni Latvijas tiesu nolēmumos. Jurista Vārds. 2013, 12(763).

48 "Ob ein Tatbestand in der Vergangenheit abgewickelt ist oder nicht, läßt sich indes vielfach nicht exakt bestimmen. Es kommt auf die subjektiv bestimmten Anknüpfungspunkte an". (It cannot be precisely defined whether the legal grounds are complete in the past or no. It depends on subjectively set linking aspects.) Papier, H.J. Verfassungsrechtliche Probleme von Übergangsrecht. Die Sozialgerichtsbarkeit. 1994, 41: 105-111. Riechelmann, F. Struktur des verfassungsrechtlichen Bestandschutzes. Rechtssicherheit als Freiheitssschutz. Norderstedt: Books on Demand, 2008, p. 31.

49 Riechelmann, F. Struktur des verfassungsrechtlichen Bestandschutzes. Rechtssicherheit als Freiheitssschutz. Norderstedt: Books on Demand, 2008, p. 34

50 Berger, T.Zulässigkeitsgrenzen der Rückwirkung von Gesetzen. Eine Kritische Analyse der Rechtsprechung des Bundesverfassungsgerichts und des Gerichtshofs der Europäischen Gemeinschaften. Frankfurt am Main: Europäischer Verlag der Wissenschaften, 2002, p. 56.

51 Heukels, T. Intertemporales Gemeinschaftsrecht. Rückwirkung, Sofortwirkung und Rechtsschutz in der Rechtsprechung des Gerichtshofes der Europäischen Gemeinschaften. Baden-Baden: Nomos Verlagsgesellschaft, 1990, p. 10-11.

52 Ruling No. 1 BvL 15/67 of 7 May 1969 by the First Senate of the Constitutional Court of Germany. Published: Entscheidungen des Bundesverfassungsgerichts, Vol. 25. Tübingen: J.C.B. Mohr (Paul Siebeck), 1969, p. 371-408 (p. 404-405). 
that retroactivity is detectable on the basis of retroactive effect of legal consequences ${ }^{53}$ has not decreased uncertainties of identification of retroactivity ${ }^{54}$.

In light of the above said, it must be admitted that regardless of continuous application of doctrine of identifying retroactivity in solving legal disputes, one of the main issues, when establishing restrictions on legislator to interfere with the past, is an objective detecting of those legal norms with a retroactive effect in time. Taking into account information available to legislator on deficiencies in doctrines of identifying retroactivity, legislator shall be able to avoid detecting retroactivity at the same time when achieving the planned aims of amendments to legal regulation ${ }^{55}$.

\subsection{Uncertainty regarding exceptions to prohibition of retroactivity}

Finally, it has to be emphasized that even if legal norm under assessment has surely a retroactive effect, it is important to understand if there are any pre-conditions to consider the retroactivity legitimate. In relation to the abovementioned, in the continental Europe it is generally acknowledged that passing of retroactive legal norms is not acceptable in a state of law ${ }^{56}$. However, as this comprehension is based not on general and absolute principle prohibiting retroactivity, but on presumption of violation of legitimate expectations of subjects of legal norms, existence of the respective concept is not absolute and shall be restricted ${ }^{57}$. In other words, both subjects of legal norms assessing benefits prescribed in the legal regulation and legislator analysing legal risks to pass immediate amendments on behalf of society have to be aware that in exceptional cases legislator regulating performed events of the past due to material reasons is acceptable. Therefore, in these cases, legitimate expectations of the subjects of legal norms have to derogate due to common interests of the society ${ }^{58}$.

It should also be noted that comparing admissibility of retroactivity in various legal systems, it can be concluded that justification for admissibility of passing retroactive legal norms differs. For example, in the German legal system, exceptions to prohibition to pass

53 Ruling No. 2 BvR 475/78 of 22 March 1983 by the Second Senate of the Constitutional Court of Germany. Published: Entscheidungen des Bundesverfassungsgerichts, Vol. 63. Tübingen: J.C.B. Mohr (Paul Siebeck), 1983, p. 343-380. Ruling No. 2 BvL 2/83 of 14 May 1986 by the Second Senate of the Constitutional Court of Germany. Published: Entscheidungen des Bundesverfassungsgerichts, Vol. 72. Tübingen: J.C.B. Mohr (Paul Siebeck), 1987, p. 200-276.

54 Hahn, H. Zur Rückwirkung im Steuerrecht. Bonn: Institut "Finanzen und Steuern”, 1987, p. 2425. Riechelmann, F. Struktur des verfassungsrechtlichen Bestandschutzes. Rechtssicherheit als Freiheitssschutz. Norderstedt: Books on Demand, 2008, p. 34.

55 See, for example, Judgement in Case No. 2010-25-01 of 6 December 2010 by the Constitutional Court of the Republic of Latvia. Latvijas Véstnesis. No. 194(4386), 08.12.2010. In the above ruling, the Constitutional Court of the Republic of Latvia was not able to detect retroactivity, as the legislator had changed legal nature of the deposit interest increase - prescribing that interest of placed deposits increase only as at the date of receipt not every day as of the commencement of the deposit placement. Therefore, the legislator was able to avoid detecting retroactivity.

56 Rensmann, T. Reformdruck und Vertrauensschutz. Juristenzeitung. 1999, 4: 168-175.

57 See, for example, Schmidt-Bleibtreu, B.; Klein, F. Kommentar zum Grundgesetz. 8th release. Berlin: Luchterhand Verlag, 1995, p. 506-507.

58 Rensmann, T. Reformdruck und Vertrauensschutz. Juristenzeitung. 1999, 4: 168-175. 
retroactive legal norms are based on ruling of 19 December 1961 by the Constitutional Court of Germany on arguments ${ }^{59}$ used to justify retroactive application of corporate income tax that have been employed further on to solve legal disputes ${ }^{60}$. Namely, passing retroactive legal norms would be acceptable in the following circumstances:

1) firstly, retroactive effect of legal norms might exist if subjects of legal norms, to which the retroactive effect applies, had to consider such changes;

2) secondly, passing of retroactive legal norms would be acceptable in cases, when legal regulation has been so unclear that legislator had to provide explanation with a retroactive effect;

3) thirdly, retroactive legal norms might be passed in cases, when legal relations previously - before adoption of amendments to legal regulation - have been regulated by an illegitimate legal norm;

4) fourthly, passing of retroactive legal norms might be acceptable in situations, when the necessity is related to general benefit that is considered more significant than interests of a state of law and legal security ${ }^{61}$.

In addition to the above legal basis, the Constitutional Court of Germany in the beginning of the 70 s of the 20th century separately also implemented the fifth basis to justify retroactive legal norms. Namely, in line with ruling of 23 March 1971 of the Constitutional Court of Germany, retroactivity would be acceptable when making exceptional immaterial amendments that would not cause significant damage ${ }^{62}$. The abovementioned base as a justification of retroactivity is related to a condition that principle of a state of law does not protect against any disappointment regarding amendments to legal regulation, but prescribes such rights only in case if amendments to legal regulation are important ${ }^{63}$.

Unlike the German law, for example, assessing situations existent in the EU law when it is possible to derogate from the principle of prohibiting retroactivity, it can be seen that case-law of the ECJ as the main source of restricting prohibition of retroactivity, derogation from retroactivity has been based on comparatively unclear

59 Ruling No. 2 BvL 6/59 of 19 December 1961 of the Second Senate of the Constitutional Court of Germany. Published: Entscheidungen des Bundesverfassungsgerichts, Vol. 13. Tübingen: Mohr Siebeck, 1963, p. 261-274 (p. 272).

60 Ruling No. 1 BvL 44, 48/92 of 15 October 1996 by the First Senate of the Constitutional Court of Germany. Published: Entscheidungen des Bundesverfassungsgerichts, Vol. 95. Tübingen: Mohr Siebeck, 1997, p. 64-96 (p. 86-87).

61 Ruling No. 2 BvL 6/59 of 10 December 1985 of the Second Senate of the Constitutional Court of Germany. Published: Entscheidungen des Bundesverfassungsgerichts, Vol. 13. Tübingen: Mohr Siebeck, 1963, p. 261-274 (p. 272).

62 Ruling No. 2 BvL 2/66, 2BvR 168, 196, 197, 210, 472/66 of 23 March 1971 by the Second Senate of the Constitutional Court of Germany. Published: Entscheidungen des Bundesverfassungsgerichts, Vol. 30. Tübingen: J.C.B. Mohr (Paul Siebeck), 1971, p. 367-392 (p. 389); see also Stötzel, M. Vertrauensschutz und Gesetzesrückwirkung. Grundtypen abgeleitet aus der Rückwirkungsrechtsprechung des Bundesverfassungsgerichts. Frankfurt am Main: Peter Lang Europäischer Verlag der Wissenschaften, 2002, p. 81.

63 Ruling No. 2 BvL 2/66, 2BvR 168, 196, 197, 210, 472/66 of 23 March 1971 by the Second Senate of the Constitutional Court of Germany. Published: Entscheidungen des Bundesverfassungsgerichts, Vol. 30. Tübingen: J.C.B. Mohr (Paul Siebeck), 1971, p. 367-392 (p. 389). 
arguments. It is quite surprising, as the EU law is mainly related to regulating persons involved in business ${ }^{64}$ that requires particular clarity of regulation of the performed operations. Therefore, the ECJ derogating from prohibition of retroactivity with no clear and objectively comprehensible criteria, there is risk of arbitrary impacting interests of subjects of legal norms.

It has to be mentioned that the ECJ has never established a systemic catalogue of pre-conditions defining cases when derogation from retroactivity principle is acceptable, i.e., stipulating thoroughly the conditions to be detected to derogate from prohibition of retroactivity. Therefore, with no similar catalogue of exceptions developed and summarized by the court including principle of inadmissibility of retroactivity, summaries and general ideas of the legal doctrine, revealing cases when the court has refused to recognize retroactive effect illegitimate, have been of a greater importance in establishing doctrine of exceptions.

For example, one of the doctrines generally acknowledges that the EU law considers retroactivity as prohibited, except if it is necessary to protect public interests and there is another cumulative pre-condition - retroactivity could have been foreseen ${ }^{65}$. However, in one of the first wide researches on inadmissibility of retroactivity in the EU law, Francois Lamoureux has specified three pre-conditions, in line with which it would be possible to derogate from the general principle of prohibition of retroactivity:

1) legislator has to clearly indicate a wish to prescribe retroactive effect, i.e., derogate from the prohibition to impact subjects of legal norms with a retroactive effect;

2) there has to be a significant public interest requiring derogation from the prohibition of retroactivity;

3) legitimate expectation of subjects of legal norms shall be observed ${ }^{66}$.

Although the abovementioned pre-conditions prima facie might seem sufficient to conclude that retroactive legal norms are legitimate, however, for the practical assessment of legal norms, those are too general to provide any precise indication as to when it is acceptable to restrict rights of subjects of legal norms. For example, the author proposing the above stated suggestions has said that to assess admissibility of retroactivity, legitimate expectations of subjects of legal norms shall be assessed together with the public interests. Regardless of the correctness of the above idea, this comprehension does not give more precise indications neither to subjects of legal norms, nor the adopters of those than the initial basis for assessment of the temporal dimension of applicability of legal norms - principle of legitimate expectations. In other words, to draw such conclusions, it is not necessary to differentiate and analyse exceptions to

64 Schlockermann, M. Rechtssicherheit als Vertrauensschutz un der Rechtsprechung des EuGH. Inaugural Dissertation zur Erlangung der Doktorwürde einer Hohen Juristischen Fakultät der Ludwig-MaximiliansUniversität zu München. 1984, p. 7-8.

65 Gilsdorf, P. Vertrauensschutz, Bestandsschutz und Rückwirkungsbegrenzung im Gemeinschaftsrecht. Recht der Internationalen Wirtschaft. 1983, 29: 22-29.

66 Lamoureux, F. The Retroactivity of Community Acts in the Case Law of the Court of Justice. Common Market Law Review. 1983, 20(2): 269-297. See also Raitio, J. The Principle of Legal Certainty in EC Law. Kluwer Academic Publishers, 2003, p. 191. 
retroactivity, as in any case assessment of legitimacy of legal norms shall be subject to uncertain contrasting of interests of the society and subjects of legal norms.

Finally, uncertainty regarding understanding of retroactivity in the EU law illustrates the Finnish legal scholar Juha Raitio, who has analysed admissibility of retroactivity from a completely different point of view ${ }^{67}$. The abovementioned author has identified five different groups of preconditions, as regards to which retroactivity has been stated as legitimate by the ECJ. Therefore, legislator has not violated general principles of law, if:

1) it has improved condition of subjects of legal norms, i.e., granting rights with a retroactive effect;

2) with a retroactive effect, compensation mechanisms stipulated by the EU law have been reduced;

3 ) it is necessary to ensure continuity of the legal relations;

4) retroactivity can be foreseen;

5) legal norms have to be interpreted ${ }^{68}$.

In order to understand the given basis to recognize retroactive legal norms as legitimate, it is important to be aware that none of the legal systems has a precise and unambiguous comprehension of the situations, where it is possible to determine exceptions to general understanding of inadmissibility of retroactivity. Therefore, as the understanding of inadmissibility of retroactivity can be interpreted, if legislator can prove that due to any reasons retroactivity is necessary and interests of subjects of legal norms shall be protected less, retroactivity as means to detect legitimate expectations of subjects of legal norms shall be applied in favour of public interest.

Also, it shall be noted that legal arguments specified in the Latvian law to justify retroactivity are too broad to allow existence of any arguments related to public interest. For example, the Constitutional Court of the Republic of Latvia, assessing existence of retroactive legal norms, has indicated that such interference in the past dimension is acceptable if it is based on protection of constitutional values ${ }^{69}$. At the same time, the Department of Administrative Cases of the Senate of the Supreme Court of Latvia has specified even a wider explanation to admissibility of retroactivity - retroactivity is acceptable in any case, when there is a reasonable basis to limit confidence of the individual in the law $^{70}$, not allowing to understand how broad is the term "reasonable basis to limit confidence in law".

67 Raitio, J. The Principle of Legal Certainty in ES Law. Kluwer Academic Publishers, 2003, p. 192-196.

68 Ibid.

$69 \S 4(2)$ of Ruling No. 2010-21-01 of 1 December 2010 by the Constitutional Court of the Republic of Latvia. Latvijas Vèstnesis. No. 192(4384), 03.12.2010; § 11 of Ruling No. 2012-21-01 of 12 June 2013 by the Constitutional Court of the Republic of Latvia. Latvijas Vèstnesis. No. 114(4920), 14.06.2013.

$70 \S 12$ of Ruling No. SKA-708/2011 of 24 November 2011 by the Department of Administrative Cases of the Senate of the Supreme Court of Latvia [interactive]. [accessed on 10-07-2013]. <http://www.at.gov. 1v/files/archive/department3/2011/708-ska-2011.doc>. 


\section{Conclusions}

1. Methodical and comprehensive restricting of legislator from interference with past dimension in the European law dimension has existed only since the second half of the 20th century. As of the abovementioned period, on basis of rulings by the Constitutional Court of Germany, legislator has a general, however, not absolute prohibition to pass retroactive legal norms. Furthermore, the retroactivity as a keystone of legitimate expectations and legal certainty principles has been implemented in legal systems of other states, not allowing uncontrolled reassessment of actions carried out in the past.

2. Establishing understanding of retroactive legal norms as unlawful, it is important to separate the general concept of retroactivity from the initial principle of the criminal law "nulla poena sine lege", stipulating a general prohibition to punish subjects of legal norms through retroactivity. Namely, the general restriction to legislator to pass retroactive legal norms in the penal law is considered as an independent general legal principle that cannot be overruled in a state of law. At the same time, retroactivity is a methodological solution to guarantee legitimate expectations and legal security of subjects of legal norms that might be replaced with other legal methods.

3. A significant problem and a challenge in future, establishing restrictions on passing retroactive legal norms, is an identification process of retroactivity. Although in certain cases it is possible to recognize retroactivity in legal norms on a basis of expresis verbis, which specified legal consequences, which are applicable prior to the date of promulgation, such situations can be detected comparatively rarely. Therefore, both legislator and subjects of legal norms, as well as constitutional courts shall not only identify retroactive legal norms applying special legal methods - the method of completeness of legal elements, the method of impact of legal consequences prior to promulgation of legal norms and the method of vested rights - but also apply those methods consistently.

4. Even if retroactivity is identified, it is important to understand that not in all cases such legal norms would be considered illegitimate. Comprehension of admissibility of retroactivity, developed within the European law dimension, due to priority of public interest in certain cases is more important than interests of legal certainty and legitimate expectations of subjects of legal norms. At the same time, it has to be admitted that exceptions to prohibition of retroactivity implemented in various legal systems are so wide and comprehensive, that only a close supervision of the goal for purposes of which the regulation has been passed with a retroactive effect it is possible to avoid using public interest to justify retroactivity.

\section{References}

Austrian Civil Code [interactive]. [accessed on 08-07-2013]. <http://www.ibiblio.org/ais/ abgb1.htm>.
Gv. Germany, No. 65210/09, ECHR.

BIMER S.A. v. Moldova, No. 15084/03, ECHR. 
Case C-113/10, Zuckerfabrik Jülich and Others [2012]. ECR 00000.

Berger, T. Zulässigkeitsgrenzen der Rückwirkung von Gesetzen. Eine kritische Analyse der Rechtsprechung des Bundesverfassungsgerichts und des Gerichtshofs der Europäischen Gemeinschaften. Frankfurt am Main: Europäischer Verlag der Wissenschaften, 2002.

Brüning, C. Die Rückwirkung von Legislativakten. Neue Juristische Wochenschrift. 1998: 1525-1528.

Case C-331/88, The Queen $v$ Ministry of Agriculture, Fisheries and Food, ex parte FEDESA and Others [1990]. ECR I-04023.

Case C-63/83, Regina v Kent Kirk [1984]. ECR 02689 .

Constitution of the Federal Republic of Germany. Bundesgesetzblatt. 1949, p. 1.

Convention for the Protection of Human Rights and Fundamental Freedoms (adopted 4 November 1950, entered into force 3 September 1953). ETS 5; 213 UNTS 221 (ECHR).

Civil Code of France [interactive]. [accessed on 08-07-2013]. <http://lexinter.net/ ENGLISH/civil_code.htm>.

Criminal Law. Latvijas Vēstnesis. 1998, No. 199/200 (1260/1261).

Fiedler, J. Neuorientierung der Verfassungsrechtsprechung zum Rückwirkungsverbot und zum Vertrauensschutz. Neue Juristische Wochenschrift. 1988: 1624-1631.

Funck, J.; Pletsch, H.J. Wann ist ein Fünfjahres(alt)vertrag kündbar? Versicherungsrecht. 2009, 13: 615.

General Law Code for the Prussian States. Cited by: Hess B. Intertemporales Privatrecht. Tübingen: Mohr Siebeck, 1998.

Gilsdorf, P. Vertrauensschutz, Bestandsschutz und Rückwirkungsbegrenzung im Gemeinschaftsrecht. Recht der Internationalen Wirtschaft. 1983, 29: 22-29.

Hahn, H. Zur Rückwirkung im Steuerrecht. Bonn: Institut "Finanzen und Steuern", 1987.

Heukels, T. Intertemporales Gemeinschaftsrecht. Rückwirkung, Sofortwirkung und
Rechtsschutz in der Rechtsprechung des Gerichtshofes der Europäischen Gemeinschaften. Baden-Baden: Nomos Verlagsgesellschaft, 1990.

Krons, M. Intertemporālo tiesību mācība un Civillikuma trešais pants. Tieslietu Ministrijas Vēstnesis. 1938, 1: 83-115.

Lamoureux, F. The Retroactivity of Community Acts in the Case Law of the Court of Justice. Common Market Law Review. 1983, 20(2): 269-297.

Latvian Code of Administrative Violations. Ziņotājs. 1984, No. 51.

Lindemann, H.H. Allgemeine Rechtsgrundsätze und europäischer öffentlicher Dienst. Berlin: Duncker \& Humblot, 1986.

Maurer, H. Kontinuitätsgewähr und Vertrauensschutz. In: Isensee, J.; Kirchhof, P. Handbuch des Staatsrechts. Band IV. Heidelberg: C.F.Müller Verlag, 2006.

Maurer, H. Staatsrecht. München: C.H. Beck'sche Verlagsbuchhandlung, 1999.

Neuhaus, K.J.; Kloth, A.; Köther, L. Neue Frist, alte Verträge - Wann ist ein Altvertrag mit mehrjähriger Laufzeit kündbar. Zeitschrift für Versicherungswesen. March 2009: 180183.

Onževs, M. Par neīsta atpakaļejoša spēka izpratni Latvijas tiesu nolēmumos. Jurista Vārds. 2013, 12(763).

Papier, H.J. Verfassungsrechtliche Probleme von Übergangsrecht. Die Sozialgerichtsbarkeit. 1994, 41: 105-111.

Raitio, J. The Principle of Legal Certainty as a General Principle of EU Law. General Principles of EC Law in a Process of Development. Kluwer Law, 2008.

Raitio, J. The Principle of Legal Certainty in EC Law. Kluwer Academic Publishers, 2003.

Rensmann, T. Reformdruck und Vertrauensschutz. Juristenzeitung. 1999, 4: 168-175.

Riechelmann, F. Struktur des verfassungsrechtlichen Bestandschutzes. Rechtssicherheit als Freiheitssschutz. Norderstedt: Books on Demand, 2008. 
Ruling No. 2 BvL 2/66, 2BvR 168, 196, 197, 210, 472/66 of 23 March 1971 by the Second Senate of the Constitutional Court of Germany. Published: Entscheidungen des Bundesverfassungsgerichts, Vol. 30. Tübingen: J.C.B. Mohr (Paul Siebeck), 1971, p. 367-392.

Ruling No. 1 BvR 14, 25, 167/52 of 30 April 1952 by the First Senate of the Constitutional Court of Germany. Published: Entscheidungen des Bundesverfassungsgerichts, Vol. 1. Tübingen: J.C.B. Mohr (Paul Siebeck), 1952, p. 264-281.

Ruling No. 1 BvR 102/51 of 24 April 1953 by the First Senate of the Constitutional Court of Germany. Published: Entscheidungen des Bundesverfassungsgerichts, Vol. 2. Tübingen: J.C.B. Mohr (Paul Siebeck), 1953, p. 237-266.

Ruling No. 2 BvR 4/59 of 31 May 1960 by the Second Senate of the Constitutional Court of Germany, Published: Entscheidungen des Bundesverfassungsgerichts, Vol. 11. Tübingen: J.C.B. Mohr (Paul Siebeck), 1961, p. 139-149.

Ruling No. 2 BvL 6/59 of 19 December 1961 by the Second Senate of the Constitutional Court of Germany. Published: Entscheidungen des Bundesverfassungsgerichts, Vol. 13. Tübingen: Mohr Siebeck, 1963, p. 261-274.

Ruling No. 1 BvL 15/67 of 7 May 1969 by the First Senate of the Constitutional Court of Germany. Published: Entscheidungen des Bundesverfassungsgerichts, Vol. 25. Tübingen: J.C.B. Mohr (Paul Siebeck), 1969, p. 371-408.

Ruling No. 1 BvR 820, 1033/76 of 21 December 1977 by the Second Senate of the Constitutional Court of Germany. Published: Entscheidungen des Bundesverfassungsgerichts, Vol. 47. Tübingen: J.C.B. Mohr (Paul Siebeck), 1978, p. 86-102.

Ruling No. 2 BvR 475/78 of 22 March 1983 by the Second Senate of the Constitutional Court of Germany. Published: Entscheidungen des Bundesverfassungsgerichts, Vol. 63.
Tübingen: J.C.B. Mohr (Paul Siebeck), 1983, p. 343-380.

Ruling No. 2 BvL 18/83 of 10 December 1985 by the Second Senate of the Constitutional Court of Germany. Published: Entscheidungen des Bundesverfassungsgerichts, Vol. 71. Tübingen: J.C.B. Mohr (Paul Siebeck), 1986, p. 255-275.

Ruling No. 2 BvL 2/83 of 14 May 1986 by the Second Senate of the Constitutional Court of Germany. Published: Entscheidungen des Bundesverfassungsgerichts, Vol. Tübingen: J.C.B. Mohr (Paul Siebeck), 1987, p. 200276.

Ruling No. 1 BvL 44, 48/92 of 15 October 1996 by the First Senate of the Constitutional Court of Germany. Published: Entscheidungen des Bundesverfassungsgerichts, Vol. 95. Tübingen: Mohr Siebeck, 1997, p. 64-96.

Ruling No. 2 BvR 2029/01 of 5 February 2004 by the Second Senate of the Constitutional Court of Germany. Published: Entscheidungen des Bundesverfassungsgerichts, Vol. 109. Tübingen: Mohr Siebeck, 2004, p. 133-190.

Ruling No. 2006-04-01 of 8 November 2006 by the Constitutional Court of the Republic of Latvia. Latvijas Vēstnesis. No. 183(3551), 15.11.2006.

02.06.2009. Regulation of Cabinet of Ministers No. 511 "Amendments to Regulation of Cabinet of Ministers No. 740 "Regulations regarding Stipends"'. Latvijas Vēstnesis. 2009, No.107(4093).

Ruling No. 2009-43-01 of 21 December 2009 by the Constitutional Court of the Republic of Latvia. Latvijas Vēstnesis. No. 201(4187), 22.12.2009.

Ruling No. 2009-86-01 of 21 April 2010 by the Constitutional Court of the Republic of Latvia. Latvijas Vēstnesis. No. 65(4257), 23.04.2010.

Ruling No. 2 BvR 748, 753, 1738/05 of 7 July 2010 by the Second Senate of the Constitutional Court of Germany. Published: Entscheidungen des Bundesverfassungsgerichts, Vol. 127. Tübingen: J.C.B. Mohr (Paul Siebeck), 2011, p. 61-87. 
Ruling No. 2010-21-01 of 1 December 2010 by the Constitutional Court of the Republic of Latvia. Latvijas Vēstnesis. No. 192(4384), 03.12.2010.

Ruling No. 2010-25-01 of 6 December 2010 by the Constitutional Court of the Republic of Latvia. Latvijas Vèstnesis. No. 194(4386), 08.12.2010.

Ruling No. SKA-708/2011 of 24 November 2011 by the Department of Administrative Cases of the Senate of the Supreme Court of Latvia [interactive]. [accessed on 10-072013]. <http://www.at.gov.lv/files/archive/ department3/2011/708-ska-2011.doc $>$.

Ruling No. 2012-21-01 of 12 June 2013 by the Constitutional Court of the Republic of Latvia. Latvijas Véstnesis. No. 114(4920), 14.06.2013.

Scheb, M. J. Criminal Law. 5th edition. Belmont: Wadsworth, 2009.

Schlockermann, M. Rechtssicherheit als Vertrauensschutz un der Rechtsprechung des $E u G H$. Inaugural Dissertation zur Erlangung der Doktorwürde einer Hohen Juristischen Fakultät der Ludwig-Maximilians-Universität zu München, 1984.

Schmidt-Bleibtreu, B.; Klein, F. Kommentar zum Grundgesetz. 8th release. Berlin: Luchterhand Verlag, 1995.
Steiner, J.; Woods, L. Textbook on EC Law. 8th edition. New York: Oxford University Press, 2003.

Stern, K. Zur Problematik Rückwirkender Gesetze. Festschrift für Theodor Maunz. Zum 80. Geburtstag. München: C.H. Becksche Verlagsbuchhandlung, 1981, p. 381-395.

Stötzel, M. Vertrauensschutz und Gesetzesrückwirkung. Grundtypen abgeleitet aus der Rückwirkungsrechtsprechung des Bundesverfassungsgerichts. Frankfurt am Main: Peter Lang Europäischer Verlag der Wissenschaften, 2002.

Vonkilch, A. Das Intertemporale Privatrecht. Übergangsfragen bei Gesetzes- und Rechtsprechungsänderungen im Privatrecht. Wien: Springer Verlag, 1999.

Wernsmann, R. Grundfälle zur Zulässigkeit rückwirkender Gesetze. Juristische. 1999, 12: 1177-1780.

,Zaļās energijas' biedrības sūdzas EK par nozares atstāšanu novārtā [interactive]. [accessed on 08-07-2013]. <http://www. delfi.lv/bizness/biznesa_vide/zalasenergijas-biedribas-sudzas-ek-par-nozaresatstasanu-novarta.d $\mathrm{id}=42844298>$.

\section{RETROAKTYVIOSIOS TEISĖKŪROS RIBOJIMAI: SAMPRATA IR TEISINIAI IŠŠÜKIAI}

\section{Māris Onževs}

Rygos universitetas, Latvija

Anotacija. Straipsnyje analizuojama įstatymu leidejo ribojimo priimti retroaktyvaus galiojimo teises normas samprata. Palaikant bütinybę riboti retroaktyvaus galiojimo teisès normu priemima, šis straipsnis atskleidžia istorini retroaktyvaus teisès normu galiojimo vystymasi ir jo doktrinos pirmini formavima Vokietijos Konstitucinio Teismo praktikoje. Taip pat straipsnyje nagrinejami keli šios temos aspektai, kurie iki šiol nebuvo tiriami, tačiau yra dideles svarbos suvokiant retroaktyvumo problematika. 
Reikšminiai žodžiai: teisés normu retroaktyvus galiojimas, teisès normu retroaktyvaus galiojimo istorinis vystymasis, Vokietijos Federalinis Konstitucinis Teismas, retroaktyvumo identifikavimas, retroaktyvumo leistinumas.

Summary. The article analyses understanding of establishing restrictions on legislators' discretion to pass retroactive legal norms, thereby protecting subjects of the legal norms from too intense impact in the past dimension. Evaluation of retroactivity as a restriction on legislators' actions is related to the fact that nowadays increasingly often there are appearing cases, when legislator implements amendments, impacting events that have been commenced in the past or that are fully completed. At the same time, neither legislator oneself, nor subjects of legal norms are aware of the cases, when legislator might have been exceeded legislator's rights to interfere with the past dimension. Therefore, to comprehend restrictions established on passing retroactive legal norms, the article views historical development, as well as actual understanding of conception of retroactive effect.

The article looks at several complex aspects, which until nowadays have been unclearly and superficially researched and, therefore, have influenced understanding of retroactivity. For example, the article justifies why a legislator, outside the penal law, does not have to comply with the absolute prohibition of retroactivity that exists mainly in the criminal law, on prohibition to punish without a law "nulla poena sine lege". Namely, although the principle stipulates an absolute prohibition to pass retroactive legal norms and is considered an independent general principle of law, the principle applies only to amendments implemented in the penal law.

In addition, the article reveals methodological problems related to both recognition of retroactivity and identification of its legitimacy. As regards the abovementioned, the article concludes that existence of retroactivity shall be mainly identified in cases, when a legislator has not included it in the content of a legal norm, and, therefore, for purposes of identifying retroactivity, comparatively complex legal methods have to be applied. However, methods implemented in the legal doctrine are discrepant and often cannot ensure a precise opinion on existence of the retroactivity.

Even if retroactivity is identified correctly, there is no consistent understanding of cases, when retroactivity could be considered legitimate. Namely, exceptions to probibition of retroactivity implemented in various legal systems are so wide and comprehensive that only a close supervision of the aims, of which the regulation was passed with a retroactive effect, it is possible to avoid groundless using of public interest to justify retroactivity.

Keywords: Retroactivity of legal norms, historical development of retroactivity, The Federal Constitutional Court of Germany, identifying retroactivity, admissibility of retroactivity.

Māris Onževs, Latvijos universiteto teisės krypties doktorantas, Turibos universiteto lektorius. Mokslinių tyrimų kryptis: teisès teorija.

Māris Onževs, PhD student of University of Latvia, lecturer at Turiba University. Research interests: theory of law. 